\title{
PENERAPAN MODEL REGRESI SPASIAL DALAM MENENTUKAN FAKTOR-FAKTOR YANG MEMPENGARUHI INDEKS PEMBANGUNAN MANUSIA DI KABUPATEN/KOTA PROVINSI SUMATERA BARAT
}

\author{
HARI SAMADI, YUDIANTRI ASDI, EFENDI \\ Jurusan Matematika, \\ Fakultas Matematika dan Ilmu Pengetahuan Alam, Universitas Andalas, \\ Kampus UNAND Limau Manis Padang, Indonesia, \\ email : arisamadi33@gmail.com
}

\begin{abstract}
Penelitian ini dilakukan untuk menentukan model indeks pembangunan manusia di kabupaten/kota Provinsi Sumatera Barat menggunakan regresi spasial, menganalisis faktor-faktor yang mempengaruhinya. Analisis yang digunakan yaitu Spatial Error Model (SEM). Hasil analisis menunjukkan bahwa peubah bebas yang mempengaruhinya adalah persentase dengan jamban sendiri, persentase kemiskinan dan angka harapan sekolah dengan nilai koefisien determinasi adalah 95,84. Nilai log likehood dari Model SEM adalah -31,3899 dan nilai Akaide Information Criterion (AIC) adalah 76,78.

Kata Kunci: Indeks pembangunan manusia, regresi spasial, model spasial galat
\end{abstract}

\section{Pendahuluan}

Suatu teknik statistika yang digunakan untuk menarik kesimpulan mengenai hubungan beberapa variabel/peubah di dalam suatu pemodelan data disebut sebagai analisis regresi. Pada pemodelan data seringkali ditemukan pengamatan pada suatu lokasi memiliki hubungan atau pengaruh dengan lokasi lain yang berdekatan. Hal ini disebut dengan ketergantungan spasial (spatial dependent). Jika kondisi ini tidak diperhatikan, maka asumsi galat antar observasi yang saling bebas secara spasial tidak terpenuhi sehingga diperlukan suatu model yang memperhatikan efek ketergantungan spasial ini. Model ini disebut dengan model ketergantungan spasial. Model ini mengembangkan analisis regresi spasial yang terdiri dari Model Autoregresi Spasial (Spatial Autoregressive Model) dan Model Galat Spasial (Spatial Error Model).

Penelitian ini akan membahas penerapan kasus ketergantungan spasial dalam suatu studi kasus yaitu Indeks Pembangunan Manusia (IPM) di Sumatera Barat. Secara umum, pembangunan Sumatera Barat terus mengalami kemajuan selama periode 2010 hingga 2015. IPM Sumatera Barat meningkat dari 67,25 pada tahun 2010 menjadi 69,98 pada tahun 2015. Selama periode tersebut, IPM Sumatera Barat rata-rata tumbuh sebesar 0,80 persen per tahun. Pada periode 2014-2015, IPM Sumatera Barat tumbuh 0,90 persen. Pertumbuhan pada periode tersebut lebih 
tinggi apabila dibandingkan dengan kenaikan pada periode 2013-2014, hanya tumbuh sebesar 0,65 persen. Meskipun selama periode 2010 hingga 2015 IPM Sumatera Barat menunjukkan kemajuan, status pembangunan Sumatera Barat masih berstatus sedang.

Pembangunan manusia merupakan salah satu indikator penting yang dapat digunakan dalam perencanaan dan evaluasi pembangunan, baik pada tingkat nasional maupun pada tingkat daerah karena manusia dipandang sebagai aset yang berharga yang memegang kunci keberhasilan dan segala macam penuntasan rencana pelaksanaan pembangunan. Pemodelan Indeks Pembangunan Manusia di tiap kabupaten/kota di Sumatera Barat perlu memasukkan efek spasial ke dalam model karena dilihat bahwa karakteristik wilayah satu kabupaten/kota mempengaruhi kabupaten/kota lain yang berada di dekatnya.

Oleh karena itu digunakan regresi spasial untuk menentukkan faktor-faktor yang mempengaruhi Indeks Pembangunan Manusia di kabupaten/kota Provinsi Sumatra Barat. Model ketergantungan spasial yang akan digunakan untuk memodelkan indeks pembangunan manusia di Sumatera Barat akan dilihat berdasarkan uji Lagrange Multiplier dan kriteria pemilihan model.

\section{Beberapa Konsep Dasar}

\subsection{Regresi Klasik dan Regresi Spasial}

Persamaan regresi klasik didefinisikan menggunakan metode kuadrat terkecil, secara umum dapat dituliskan:

$$
y=X \beta+\epsilon
$$

dengan y adalah matriks peubah tak bebas berukuran $n \times 1$, X adalah matriks peubah bebas berukuran $n \times p$, n adalah jumlah lokasi, $\beta$ adalah matriks koefisien parameter regresi yang berukuran $p \times 1$ dan $\epsilon$ adalah matriks galat berukuran $n \times 1$. Asumsi yang harus dipenuhi pada model regresi klasik adalah:

(1) $\mathrm{E}\left(\epsilon_{i}\right)=0$ (Nilai harapan setiap galat sama dengan nol).

(2) $\operatorname{Var}\left(\epsilon_{i}^{2}\right)=\sigma^{2}$ (Mempunyai varian yang sama)

(3) $\mathrm{E}\left(\epsilon_{i} \epsilon_{j}\right)=0$ (galat $\epsilon_{i}$ tidak berkorelasi terhadap galat $\epsilon_{j}$ ).

Regresi spasial merupakan suatu analisis untuk mengevaluasi hubungan antara satu peubah dengan beberapa peubah lain dengan memperhatikan pengaruh spasial (wilayah). Model umum regresi spasial adalah sebagai berikut:

$$
\begin{aligned}
y & =\rho W y+X \beta+u, \\
u & =\lambda W u+\epsilon, \\
\epsilon_{i} & \sim N\left(0, \sigma^{2} I\right)
\end{aligned}
$$

dengan y adalah matriks peubah tak bebas berukuran $n \times 1, \rho$ adalah koefisien lag spasial, W adalah matriks pembobot spasial yang berukuran $n \times n$, X adalah matriks peubah bebas berukuran $n \times p$, n adalah jumlah lokasi, $\beta$ adalah matriks koefisien parameter regresi yang berukuran $p \times 1, \lambda$ adalah koefisien galat spasial, $\mathrm{u}$ 
adalah matriks galat yang mengandung autokorelasi berukuran $n \times 1$ dan I adalah matriks identitas dengan ukuran $n \times n$.

\subsection{Model Autoregresi Spasial (SAR)}

Model SAR merupakan model regresi linier yang pada peubah tak bebasnya terdapat korelasi spasial. Model umum untuk SAR adalah sebagai berikut:

$$
\begin{aligned}
y & =\rho W y+X \beta+\epsilon, \\
\epsilon_{i} & \sim N\left(0, \sigma^{2} I\right),
\end{aligned}
$$

koefisien lag spasial $(\rho)$ menunjukan tingkat korelasi pengaruh spasial dari suatu wilayah terhadap wilayah lain disekitarnya.

\subsection{Model Galat Spasial (SEM)}

SEM adalah model regresi linier yang pada galatnya terdapat korelasi spasial. Model umum untuk SEM adalah sebagai berikut:

$$
\begin{aligned}
y & =X \beta+u, \\
u & =\lambda W u+\epsilon, \\
\epsilon_{i} & \sim N\left(0, \sigma^{2} I\right),
\end{aligned}
$$

koefisien galat spasial $(\lambda)$ menunjukkan tingkat korelasi pengaruh galat spasial dari suatu wilayah terhadap wilayah lain di sekitarnya.

\subsection{Matriks Pembobot Spasial}

Matriks pembobot spasial pada dasarnya merupakan matriks ketergantungan spasial (contiguity) dengan notasi W. Matriks C adalah matriks yang menggambarkan hubungan antar daerah dan diperoleh berdasarkan informasi jarak atau ketetanggan. Matriks $\mathrm{C}$ mempunyai entri $c_{i j}=1$ jika dua pengamatan i dan $\mathrm{j}$ dianggap berhubungan (bertetanggaan), dan $c_{i j}=0$ jika tidak berhubungan antara pengamatan i dan j. Matriks W adalah matriks $\mathrm{C}$ yang sudah di standarkan dengan normalisasi baris dimana jumlah tiap baris $c_{i}$ sama dengan 1 dan diagonal dari matriks ini umumnya diisi dengan nilai nol. Dimensi dari matriks ini adalah $n \times n$, dimana $n$ adalah banyaknya lokasi. Isi dari matriks pembobot spasial pada baris ke-i dan kolom ke-j adalah $w_{i j}$. Nilai $w_{i j}$ pada penelitian ini adalah:

$$
w_{i j}=\frac{c_{i j}}{\sum_{t=1}^{k} c_{i j}}
$$

\subsection{Indeks Moran}

Koefisien Moran $I$ atau Indeks Moran digunakan untuk uji dependensi spasial atau autokorelasi antar lokasi. Hipotesis yang digunakan adalah:

$$
\begin{aligned}
& H_{0}=\text { tidak ada autokorelasi antar lokasi } \\
& H_{1}=\text { ada autokorelasi antar lokasi. }
\end{aligned}
$$


Persamaan indeks Moran adalah sebagai berikut:

$$
I=\frac{n \sum_{j \neq i}^{k} w_{i j}\left(y_{i}-\bar{y}\right)\left(y_{j}-\bar{y}\right)}{\left(\Sigma_{i} \Sigma_{j \neq i}\right) \sum i\left(y_{i}-\bar{y}\right)^{2}} .
$$

Pengambilan keputusan $H_{0}=$ ditolak jika $\left|Z_{\text {hitung }}\right|>Z_{\alpha / 2}$, dimana:

$$
\left|Z_{\text {hitung }}\right|=\frac{I-I_{0}}{\sqrt{\operatorname{var}(I)}}
$$

\subsection{Identifikasi Efek Spasial}

Efek spasial yaitu ketergantungan spasial terjadi akibat adanya korelasi antar wilayah yang terdiri ketergantungan lag dan galat spasial. Kedua efek ini dapat diuji dengan menggunakan uji Lagrange Multiplier (LM). Hasil yang diperoleh dari uji LM akan dijadikan dasar dalam pembentukan model regresi spasial.

\subsection{Uji Breusch Pagan (BP)}

Pada model regresi spasial, uji BP digunakan untuk mendeteksi asumsi kehomogenan ragam galat. Hipotesis yang diuji adalah sebagai berikut:

$$
\begin{aligned}
& H_{0}=\text { ragam homogen } \\
& H_{1}=\text { ragam tidak homogen. }
\end{aligned}
$$

Statistik Uji:

$$
B P=\left(\sum_{i=1}^{n} x_{i} f_{i}\right)\left(\sum_{i=1}^{n} x_{i} x_{i}^{T}\right)\left(\sum_{i=1}^{n} x_{i} f_{i}\right)
$$

statistik uji BP menyebar $\chi_{(k-1)}^{2}$ dengan $\mathrm{k}$ adalah banyaknya parameter regresi. Keputusan tolak $H_{0}$ dilakukan jika nilai statistik uji BP lebik besar dari $\chi_{(k-1)}^{2}$.

\subsection{Kriteria Pemilihan Model}

Model dikatakan baik jika jika nilai AIC lebih kecil, nilai log likehood yang besar dan mempunyai nilai koefisien determinasi $\left(R^{2}\right)$ yang besar.

\section{Data dan Metode Penelitian}

Pada penelitian ini data yang digunakan merupakan data sekunder yaitu dari Data dan informasi Kemiskinan dan data dari Berita Resmi Statistik Sumatera Barat tentang Indeks Pembangunan Manusia.

Peubah yang digunakan dalam penelitian ini adalah indeks pembangunan manusia sebagai peubah tak bebas $(Y)$ dan terdiri dari 8 peubah bebas yaitu Persentase penduduk yang tidak tamat SD $\left(X_{1}\right)$, Persentase rumah dengan jamban sendiri $\left(X_{2}\right)$, Persentase rumah tangga penerima raskin $\left(X_{3}\right)$, Persentase bantuan pemerintah yang diberikan kepada masyarakat $\left(X_{4}\right)$, Persentase kemiskinan $\left(X_{5}\right)$, Persentase penduduk yang tidak bekerja $\left(X_{6}\right)$, Persentase penduduk yang bekerja disektor informal $\left(X_{7}\right)$, Angka Harapan Sekolah $\left(X_{8}\right)$.

Adapun langkah-langkah analisis data yang dilakukan dalam penelitian ini adalah sebagai berikut : 
1) Melakukan pendugaan dan pengujian parameter model regresi klasik serta menguji asumsi galat (uji homogenitas, uji autokorelasi dan uji normalitas).

2) Menentukan matriks pembobot spasial W.

3) Menentukan nilai Indeks Moran dari model regresi klasik (biasa).

4) Menguji efek spasial yaitu uji dependensi spasial dilakukan dengan uji Lagrange Multiplier (LM) dan uji keragaman spasial dilakukan dengan uji BreuschPagan.

5) Menduga parameter untuk persamaan model regresi spasial dengan metode penduga kemungkinan maksimum.

6) Memeriksa asumsi pada model regresi yang dihasilkan yaitu kenormalan galat diuji secara formal dengan uji Kolmogorov-Smirnov. Kehomogenan ragam galat diuji menggunakan uji Breusch-Pagan.

7) Memilih model terbaik antara model regresi biasa dengan model regresi spasial dengan menggunakan nilai koefisien determinasi $\left(R^{2}\right)$, AIC,log likehood.

8) Menentukan faktor-faktor yang mempengaruhi Indeks Pembangunan Manusia berdasarkan model terbaik.

\section{Hasil dan Pembahasan}

Berikut adalah gambaran umum dari indeks pembangunan manusia di kabupaten/kota Provinsi Sumatera Barat pada tahun 2015.

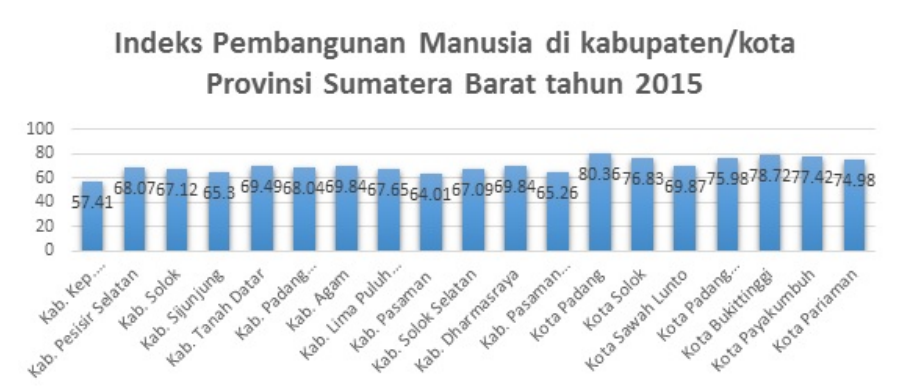

Gambar 1. IPM di kabupaten/kota Provinsi Sumatera Barat

Grafik pada Gambar 1 menunjukkan bahwa nilai IPM terbesar dimiliki oleh Kota Padang yaitu sebesar 80,36, sedangkan nilai IPM terendah dimiliki oleh Kabupaten Kepulauan Mentawai yaitu sebesar 57,41. Adapun masing-masing tetangga dari setiap kabupaten/kota di Provinsi Sumatera Barat dapat dilihat pada Peta wilayah kabupaten/kota Provinsi Sumatera Barat disajikan pada Gambar 2.

\subsection{Model Regresi Klasik}

Pemodelan menggunakan model regresi klasik didapatkan peubah $X_{8}$ (Angka Harapan Sekolah) yang berpengaruh secara signifikan dengan $\alpha=0,05$. Persamaan 


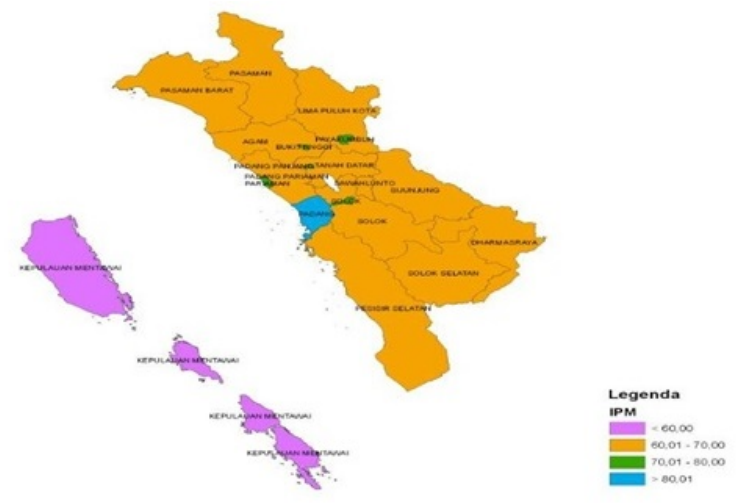

Gambar 2. Peta Wilayah kabupaten/kota Provinsi Sumatera Barat.

regresi klasik yang terbentuk menggunakan metode kuadrat terkecil (MKT) adalah: $\hat{y}=44,63809+0,01066 X_{1}+0,03441 X_{2}+0,01485 X_{3}+0,04611 X_{4}-0,067332 X_{5}$ $-0,014510 X_{6}-0,11269 X_{7}+2,83345 X_{8}$,

Persamaan regresi yang terbentuk mempunyai nilai $R^{2}$ sebesar $94,73 \%$ yang berarti model regresi dapat menjelaskan keragaman Indeks Pembangunan Manusia sebesar 94,73\%, sedangkan sisanya sebesar 5,27\% dijelaskan oleh peubah lain diluar model.

\subsection{Matriks Pembobot Spasial}

Matriks pembobot spasial dibentuk dengan melakukan normalisasi terlebih dahulu. Normalisasi dilakukan untuk memperoleh rataan dari wilayah yang mengelilingi suatu kabupaten/kota. Metode yang dapat digunakan untuk menormalisasi matriks tersebut adalah normalisasi baris.

\subsection{Indeks Moran}

Pengujian Indeks Moran dilakukan dengan menentukan matriks pembobot terlebih dahulu. Matriks pembobot yang telah diperoleh kemudian dilakukan standarisasi baris. Hasil Indeks Moran untuk sisaan model MKT Indeks Pembangunan Manusia memperoleh nilai Indeks Moran sebesar -0,11349251 dengan nilai-p sebesar 0,641 yang lebih besar dari $\alpha=0,05$. Hal ini menunjukkan bahwa tidak terdapat autokorelasi spasial pada Indeks Pembangunan Manusia.

\subsection{Identifikasi Efek Spasial}

Identifikasi ini bertujuan untuk mengetahui adanya ketergantungan spasial pada model regresi yang berpengaruh terhadap Indeks Pembangunan Manusia. Uji Lagrange Multiplier (LM) dilakukan untuk menguji efek ketergantungan spasial dalam 
lag dan galat. Hasil yang diperoleh dari uji LM akan dijadikan dasar dalam pembentukan model regresi spasial.

Tabel 4.1. Hasil uji ketergantungan spasial dengan uji LM

\begin{tabular}{|c|c|c|}
\hline Model & Nilai uji LM & Nilai p-value \\
\hline Model SAR & 0,26627 & 0,6058 \\
\hline Model SEM & 5,3999 & 0,02014 \\
\hline
\end{tabular}

Berdasarkan tabel diatas didapatkan nilai p-value pada model galat spasial yang lebih kecil dari $\alpha=0,05$ sehingga disimpulkan tolak $H_{0}$ artinya terdapat ketergantungan galat spasial sehingga dapat dilanjutkan pada pembentukkan model SEM. Uji LM pada model spasial lag memberikan nilai-p yang lebih besar dari $\alpha=0,05$ yang menunjukkan bahwa tidak terdapat lag spasial sehingga tidak dapat dilanjutkan pada pembentukkan model spasial lag.

\subsection{Model Galat Spasial (SEM)}

Pemodelan menggunakan model galat spasial didapatkan peubah $X_{2}$ (persentase rumah dengan jamban sendiri), $X_{5}$ (persentase kemiskinan), $X_{6}$ (persentase penduduk yang tidak bekerja), $X_{8}$ (angka harapan sekolah) dan galat spasial $(\lambda)$ berpengaruh terhadap Indeks Pembangunan Manusia di Provinsi Sumatera Barat yang berpengaruh secara signifikan dengan $\alpha=0,05$. Model regresi yang terbentuk pada indeks pembangunan manusia menggunakan model spasial galat adalah:

$y_{i}=35,7299595+0,0070927 X_{1 i}+0,0374210 X_{2 i}-0,0048675 X_{3 i}+0,0256240 X_{4 i}$ $-0,3908690 X_{5 i}-0,1426897 X_{6 i}-0,1088040 X_{7 i}+3,4085598 X_{8 i}+u_{i}$,

$u_{i}=0,77069 \Sigma_{j=1, i \neq j}^{n} w_{i j} u j+\epsilon_{i}$, dimana $i=1,2,3, \cdots, 19$,

dimana

$$
\begin{aligned}
y_{i} & =\text { IPM di kabupaten kota ke-i } \\
u_{i} & =\text { galat spasial dari kabupaten/kota ke-i } \\
u_{j} & =\text { galat spasial dari tetangga kabupaten/kota ke-i } \\
w_{i j} & =\text { elemen matriks pembobot spasial yang sudah dinormalisasi baris. }
\end{aligned}
$$

Selanjutnya akan dicari hasil pendugaan dan pengujian parameter Model SEM dengan menggunakan empat peubah yang berpengaruh dapat dilihat pada Tabel 4.2

$$
\begin{aligned}
& y_{i}=18,699021+0,043822 X_{2 i}-0,024791 X_{5 i}+4,002774 X_{8 i}+u_{i}, \\
& u_{i}=0,6846 \Sigma_{j=1, i \neq j}^{n} w_{i j} u j+\epsilon_{i}, \text { dimana } i=1,2,3, \cdots, 19,
\end{aligned}
$$

Berdasarkan model yang terbentuk didapatkan peubah yang berpengaruh pada taraf 0,05 yaitu peubah $X_{2}$ (persentase rumah dengan jamban sendiri), $X_{5}$ (persentase kemiskinan), $X_{8}$ (angka harapan sekolah) dan koefisien $\lambda$. 
Tabel 4.2. Pendugaan dan pengujian parameter model SEM dengan empat peubah yang berpengaruh

\begin{tabular}{|c|c|c|}
\hline Prediktor & Koefisien & Nilai- $p$ \\
\hline Intersep & 18,699021 & 0,0009077 \\
\hline $\mathrm{X}_{2}$ & 0,043822 & 0,0011067 \\
\hline $\mathrm{X}_{5}$ & -0431102 & 0,0083817 \\
\hline $\mathrm{X}_{6}$ & $-0,24791$ & 0,5532594 \\
\hline $\mathrm{X}_{8}$ & 4,002774 & 0,0000000 \\
\hline$\lambda$ & 0,6846 & 0,018058 \\
\hline
\end{tabular}

\subsection{Interpretasi Model Galat Spasial (SEM)}

Koefisien $\lambda$ menunjukkan adanya hubungan Indeks Pembangunan Manusia pada suatu wilayah dengan wilayah lainnya yang berdekatan. Misalnya IPM di kabupaten Tanah Datar yaitu sebesar 69,49, kalau di lihat berdasarkan wilayah yang bertetanggaan dengan Kabupaten Tanah Datar rata-rata mempunyai nilai IPM yang relatif sama. Nilai IPM di Kabupaten Agam sebesar 69,84, kalau dilihat berdasarkan wilayah yang bertetanggaan dengan Kabupaten Agam rata-rata mempunyai nilai IPM yang relatif sama. Kabupaten Padang Pariaman memiliki IPM sebesar 68,04, kalau dilihat berdasarkan wilayah yang bertetanggaan dengan Kabupaten Padang Pariaman rata-rata mempunyai nilai IPM yang relatif sama. Setiap peningkatan peubah persentase rumah dengan jamban sendiri sebesar satu satuan akan meningkatkan Indeks Pembangunan Manusia sebesar 0,043822 satuan dengan asumsi peubah-peubah yang selainnya dianggap konstan.

Koefisien peubah persentase kemiskinan sebesar -0,431102 menunjukkan bahwa setiap peningkatan persentase kemiskinan di kabupaten/kota Provinsi Sumatera Barat sebesar satu persen akan menurunkan Indeks Pembangunan Manusia sebesar 0,431102 dengan asumsi peubah lain dianggap konstan. Ini menunjukkan bahwa untuk meningkatkan Indeks Pembangunan Manusia harus menurunkan persentase kemiskinan di kabupaten/kota Provinsi Sumatera Barat. Setiap peningkatan peubah angka harapan sekolah sebesar satu satuan akan meningkatkan Indeks Pembangunan Manusia sebesar 4,002774 satuan dengan asumsi peubah-peubah yang selainnya dianggap konstan.

\subsection{Pemilihan Model}

Kriteria yang digunakan untuk memilih model adalah nilai AIC beserta log likehood dan $R^{2}$. Untuk Nilainya dapat dilihat pada Tabel 4.3.

Model dikatakan baik jika memiliki nilai AIC yang kecil dan memperoleh nilai log likehood yang lebih besar, serta mempunyai nilai $R^{2}$ yang lebih besar. Tabel 4.3 menunjukkan bahwa nilai AIC yang lebih kecil, nilai loglikehood dan nilai $R^{2}$ yang besar terdapat pada Model SEM sehingga model yang dipilih untuk menganalisis kasus ketergantungan spasial Indeks Pembangunan Manusia di Provinsi Sumatera 
Tabel 4.3. Nilai pemilihan Model

\begin{tabular}{|c|c|c|}
\hline Nilai & Regresi Biasa & SEM \\
\hline AIC & 84,026 & 76,78 \\
\hline log likehood & $-32,01296$ & $-31,3899$ \\
\hline $\mathrm{R}^{2}$ & 94,73 & 95,84 \\
\hline
\end{tabular}

Barat adalah Model SEM dengan peubah yang berpengaruh didapatkan peubah $X_{2}$ (persentase rumah dengan jamban sendiri), $X_{5}$ (persentase kemiskinan), $X_{8}$ (angka harapan sekolah) dan koefisien $\lambda$.

\section{Kesimpulan}

Berdasarkan hasil analisis dan pembahasan dapat diambil kesimpulan sebagai berikut:

1. Model Galat spasial (SEM) lebih baik dibandingkan model regresi klasik(biasa) dalam menentukkan faktor-faktor yang mempengaruhi Indeks Pembangunan Manusia di kabupaten/kota Sumatera Barat. Model SEM yang terbentuk adalah :

$$
\begin{aligned}
& y_{i}=18,699021+0,043822 X_{2 i}-0,024791 X_{5 i}+4,002774 X_{8 i}+u_{i}, \\
& u_{i}=0,6846 \Sigma_{j=1, i \neq j}^{n} w_{i j} u j+\epsilon_{i}, \operatorname{dimana} i=1,2,3, \cdots, 19,
\end{aligned}
$$

berdasarkan model yang terbentuk didapatkan peubah yang berpengaruh pada taraf $=0,05$ yaitu peubah $X_{2}$ (persentase rumah dengan jamban sendiri), $X_{5}$ (persentase kemiskinan), $X_{8}$ (angka harapan sekolah) dan koefisien $\lambda$

2. Berdasarkan model terbaik yang didapatkan yaitu model spasial galat maka faktor-faktor yang mempengaruhi indeks pembangunan manusia di kabupaten/kota Provinsi Sumatera Barat adalah persentase rumah dengan jamban sendiri, persentase kemiskinan dan angka harapan sekolah.

\section{Ucapan Terima Kasih}

Penulis mengucapkan terimakasih kepada Bapak Dodi Devianto, Zulakmal, dan Ibu Radhiatul Husna yang telah memberikan masukan dan saran sehingga paper ini dapat diselesaikan dengan baik.

\section{Daftar Pustaka}

[1] Anselin, L. 1988. Spatial Econometrics: Method and Models. Academic Publishers, Dordrecht

[2] Anselin, L. 2001. Spatial Econometrics. Blackwell Publishing Ltd. Diedit oleh Badi H. Baltagi

[3] Badan Pusat Statistik. 2015. Data dan Informasi Kemiskinan. Jakarta: Badan Pusat Statistik 
Indeks Pembangunan Manusia Di Kabupaten/Kota Provinsi Sumatera Barat 89

[4] Badan Pusat Statistik. 2016. Indeks Pembangunan Manusia. Padang: Badan Pusat Statistik

[5] Draper NR, H. Smith. 1998. Applied Regression Analysis. University of Wisconsin: Departement of Statistics

[6] Kosfel, Reinhold. 2016. Spatial Econometrics with R. University of Kassel:Economics Department

[7] Ward MD, Kristiani SG. 2008. Spatial Regression Models Series: Quantitative Application in the Social Science. California : Sage Publication, Inc.

[8] Supranto, J. 2001. Statistik Teori dan Aplikasi. Edisi ke Enam. Erlangga, Jakarta 